\title{
Synthesis, Antiproliferative and Antimalarial Activities of Dinuclear Silver(I) Complexes with Triphenylphosphine and Thiosemicarbazones Ligands
}

\author{
Nur Adila Fatin Mohd Khir', Mohd Ridzuan Mohd Abd Razak², Fariza Juliana Nordin ${ }^{3}$, Nur Rahimah \\ Fitrah Mohd Sofyan ${ }^{1}$, Nor Fadilah Rajab ${ }^{3}$, and Rozie Sarip ${ }^{1^{*}}$
}

${ }^{1}$ Department of Chemistry, Faculty of Science, University of Malaya (UM), Lembah Pantai, 50603 Kuala Lumpur, Malaysia

${ }^{2}$ Bioassay Unit, Herbal Medicine Research Centre (HMRC), Institute for Medical Research (IMR),

Jl. Pahang, 50588 Kuala Lumpur, Malaysia

${ }^{3}$ Faculty of Health Sciences, Universiti Kebangsaan Malaysia (UKM), Kuala Lumpur Campus,

Jl. Raja Muda Abdul Aziz, 50300 Kuala Lumpur, Malaysia

\section{* Corresponding author:}

tel: $+603-79677022$ ext. 2534

email: rozie@um.edu.my

Received: June 30, 2020

Accepted: September 20, 2020

DOI: $10.22146 / \mathrm{ijc} .57343$

\begin{abstract}
A series of six sulfur-bridged dinuclear silver(I) thiosemicarbazone complexes were synthesized through the reaction of silver(I) nitrate with 4-phenyl-3thiosemicarbazone derivatives together with triphenylphosphine $\left(P P h_{3}\right)$ (in a 1:1:2 molar ratio). Following structural characterizations using various techniques such as elemental analysis, Fourier-transform infrared (FTIR) spectroscopy, as well as ${ }^{1} \mathrm{H},{ }^{13} \mathrm{C},{ }^{31} \mathrm{P}\left\{{ }^{1} \mathrm{H}\right\}$, COSY, and ${ }^{1} \mathrm{H}_{-}{ }^{13} \mathrm{C}$ nuclear magnetic resonance (NMR) spectroscopy, it was found that the thiosemicarbazone ligand exists in the form of a thione rather than thiol tautomer. Subsequently, MDA-MB-231 and MCF-7 breast cancer cell lines, as well as the HT-29 colon cancer cell lines, were used to investigate the in vitro antiproliferative activities of these complexes. In all cases, the $I C_{50}$ values were in the potent micromolar range. Besides, the aforementioned complexes also had good antiplasmodial activity against chloroquine-resistant P. falciparum, as per the results of histidine-rich protein 2 (HRP2) assays and cytotoxicity evaluations of MDBK cells.
\end{abstract}

Keywords: thiosemicarbazone; silver complexes; antiplasmodial; antiproliferative; phosphine

\section{- INTRODUCTION}

The synthesis of metal complexes containing mixed ligand systems that have electron-donating potential has attracted much attention owing to their catalytic abilities [1], unique structures [2], and most importantly, applications in the medical field [3-4]. In particular, metal complexes with phosphine and thiosemicarbazone ligands have been explored due to the ability of thiosemicarbazone to coordinate a wide range of metallic ions that can be attributed to the extended delocalization of the electron density of the NH-CS-NH-N system [5]. The employment of transition metals in drug discovery has become a favorite approach, especially when it is attached to compounds of common therapeutic value like thiosemicarbazones in an effort to fight drug resistance
[6]. In addition, metal coordination also helps to increase the lipophilicity of a compound, hence increasing the speed of the compound's entry into the cell [7].

Research interest in these compounds is also fueled by their broad spectrum of biological activities, including antibacterial [8], antiviral [9], antitubercular [10], and antitumor [11], anticancer and antimalarial activities [5]. Evidently, silver complexes and their therapeutic abilities are interesting topics among researchers [12]. A previous study combining the ligands of thio and phosphine has shown a promising activity towards antibacterial activity [13]. Another study used a similar group of ligands (thio and phosphine), but gold also showed higher cytotoxicity, better antitumor activity, 
and selectivity than the cisplatin [14]. However, to the ability of our knowledge, there is a lacking recent report on the screening for the anticancer potential and the antiplasmodial properties of the silver(I) complexes with thiosemicarbazone and triphenylphosphine ligands.

Hence, as a part of continuing interest in this area of research, we synthesized a series of thiosemicarbazonederivative ligands, which were then attached to a silver center along with triphenylphosphine ligands. The silver complexes were later characterized using few elemental and spectral analyses to confirm their structure. Basic elemental analysis like CHNS and PXRD was used to confirm the composition and types of elements present in the complexes. Afterward, more detailed spectroscopy techniques like FTIR, 1D NMR, and 2D NMR were used to justify the structure of the complexes.

\section{- EXPERIMENTAL SECTION}

\section{Materials}

Chemicals of 4-nitrobenzaldehyde, 4-hydroxy benzaldehyde, 5-bromosalicylaldehyde, 5-bromoindole3-carboxaldehyde (98\%, Sigma Aldrich), 2-methylindole3-carboxaldehyde, (5-bromo-2-hydroxy-3-methoxy benzaldehyde (97\%, Sigma Aldrich), triphenylphosphine, 4-phenyl thiosemicarbazide (99\%, Sigma Aldrich) were used in this study. All reagents and solvents used were of reagent grade without prior purification unless otherwise stated. The progress of these reactions was observed via thin-layer chromatography performed on $2.00 \times 6.00 \mathrm{~cm}$ aluminium sheets pre-coated with silica gel 60 (HF-254, Merck) of thickness $0.25 \mathrm{~mm}$.

\section{Instrumentation}

The Fourier-transform infrared (FTIR) spectra were recorded by a Perkin Elmer Spectrum One FT-IR spectrophotometer (ATR) at $450-4000 \mathrm{~cm}^{-1}$. The ${ }^{1} \mathrm{H},{ }^{13} \mathrm{C}$, ${ }^{31} \mathrm{P}\left\{{ }^{1} \mathrm{H}\right\}, \mathrm{COSY}$, and ${ }^{1} \mathrm{H}_{-}{ }^{13} \mathrm{C}$ nuclear magnetic resonance (NMR) spectra were analyzed using a JEOL FT-NMR ECX 400 (ECX 400) spectrometer, whereby deuterated dimethyl sulfoxide (DMSO) and chloroform were the solvents. Meanwhile, Perkin Elmer CHNS/O Analyzer 2400 Series II was used to perform the elemental analyses, while Energy Dispersive X-Ray spectroscopy (EDX) was used to detect the presence of silver metal. X-ray diffractometer (PANalytical, Netherlands) was used to examine Powder X-ray diffraction (PXRD) with a scanning scope of $2 \theta$ from 0 to $50^{\circ}$ and scanning rate of $4.25^{\circ} / \mathrm{min}$ at room temperature $\left(25^{\circ} \mathrm{C}\right)$, with $\mathrm{Cu} \mathrm{Ka}$ characteristic radiation $(\lambda=0.154 \mathrm{~nm})$ at the current of $40 \mathrm{~mA}$ and voltage of $40 \mathrm{kV}$.

\section{Procedure}

\section{Synthesis of thiosemicarbazone ligands (L1-L6)}

All thiosemicarbazone ligands (L1-L6) were prepared by the procedure described in Ref. [15], with slight modifications (Scheme 1). First, 4-phenyl-3thiosemicarbazide (1 g, $6 \mathrm{mmol}$ ) was dissolved in ethanol $(33 \mathrm{~mL})$. Next, the corresponding aldehyde (which was pre-dissolved in ethanol) was added to the mixture along with a few small drops of glacial acetic acid. The solution was then refluxed for 3-4 $\mathrm{h}$ and later dried in a vacuum for analysis. The ligands were white or yellow powders soluble in ethanol, methanol, acetone, DMSO, dichloromethane, or chloroform.

L1: 4-nitrobenzaldehyde- $\mathrm{N}$-phenyl-thiosemicarba zone. Yield: $70 \%$, M.p. $260{ }^{\circ} \mathrm{C}$. Anal. Calc. for $\mathrm{C}_{14} \mathrm{H}_{12} \mathrm{~N}_{4} 0_{2} \mathrm{~S}$ : C, 56.00; H, 4.02; N, 18.63. Found: C, 55.20; $\mathrm{H}, 3.73$; N, 18.59. IR data $\left(\mathrm{cm}^{-1}\right):(\mathrm{N}-\mathrm{H}) 3103.08,2980.20$,<smiles>[R]C=NNC(=S)Nc1ccccc1</smiles>

L1: R:

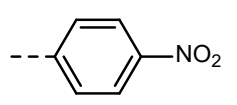

L2: R:

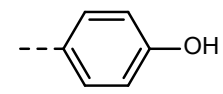

L3: R:

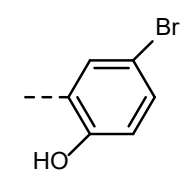

L4: R:<smiles>CC1Nc2ccccc2C1C</smiles>

L5: R:<smiles>CC1CNc2ccc(Cl)cc21</smiles>

L6: R:

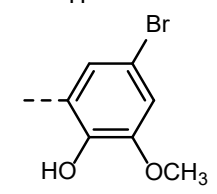

Scheme 1. Synthesis of thiosemicarbazone ligands 
$(\mathrm{C}=\mathrm{N})$ 1595.02, $(\mathrm{C}=\mathrm{S})$ 846.76, ${ }^{1} \mathrm{H}-\mathrm{NMR}$ data $(\delta, \mathrm{ppm}$; DMSO): $12.06(\mathrm{~s}, 1 \mathrm{H})(\mathrm{N}-\mathrm{H}), 10.29(\mathrm{~s}, 1 \mathrm{H})(\mathrm{N}-\mathrm{H}), 8.20$ $(\mathrm{C}-\mathrm{H}, 1 \mathrm{H})(\mathrm{CH}=\mathrm{N}), 7.2-8.2(\mathrm{~m})\left(\mathrm{CH}, \mathrm{CH}_{2}, \mathrm{CH}_{3}\right) ;{ }^{13} \mathrm{C}-$ NMR data ( $\delta$, ppm; DMSO): $177.10(\mathrm{C}=\mathrm{S}), 140.70(\mathrm{C}-\mathrm{Ph})$. L2: 4-hydroxybenzaldehyde- $\mathrm{N}$-phenyl-thiosemicar bazone. Yield: $60 \%$, M.p. $240{ }^{\circ} \mathrm{C}$. Anal. Calc. for $\mathrm{C}_{14} \mathrm{H}_{13} \mathrm{~N}_{3} \mathrm{OS}$ : C, 61.97; H, 4.83; N, 15.49. Found: C, 61.24; $\mathrm{H}, 4.92 ; \mathrm{N}, 14.98$. IR data $\left(\mathrm{cm}^{-1}\right):(\mathrm{N}-\mathrm{H}) 3158.08,2977.11$ $(\mathrm{C}=\mathrm{N}) 1604.28(\mathrm{C}=\mathrm{S})$ 851.49, ${ }^{1} \mathrm{H}-\mathrm{NMR}$ data $(\delta$, ppm; DMSO): $11.62(\mathrm{~s}, 1 \mathrm{H})(\mathrm{N}-\mathrm{H}), 9.94(\mathrm{~s}, 1 \mathrm{H})(\mathrm{N}-\mathrm{H}), 9.88(\mathrm{~s}$, $1 \mathrm{H})(\mathrm{C}-\mathrm{OH}), 8.04(\mathrm{~s}, 1 \mathrm{H})(\mathrm{CH}=\mathrm{N}), 6.8-8.1(\mathrm{~m})(\mathrm{CH}$, $\mathrm{CH} 2, \mathrm{CH} 3) ;{ }^{13} \mathrm{C}-\mathrm{NMR}$ data $(\delta, \mathrm{ppm} ; \mathrm{DMSO}): 175.90$ $(\mathrm{C}=\mathrm{S}), 144.00(\mathrm{C}-\mathrm{Ph})$.

L3: 5-bromo-2-hydroxybenzaldehyde-N-phenyl-thio semicarbazone. Yield: $65 \%$, M.p. $250^{\circ} \mathrm{C}$. Anal. Calc. for $\mathrm{C}_{14} \mathrm{H}_{12} \mathrm{BrN}_{3} \mathrm{OS}$ : C, 48.01; H, 3.45; N, 12.00. Found: C, 48.24; $\mathrm{H}, 3.44 ; \mathrm{N}, 12.12$. IR data $\left(\mathrm{cm}^{-1}\right):(\mathrm{N}-\mathrm{H}) 3141.28$, $2984.50(\mathrm{C}=\mathrm{N}) 1604.57(\mathrm{C}=\mathrm{S}) 829.04,{ }^{1} \mathrm{H}-\mathrm{NMR}$ data $(\delta$, ppm; DMSO): $11.78(\mathrm{~s}, 1 \mathrm{H})(\mathrm{N}-\mathrm{H}), 10.14(\mathrm{~s}, 1 \mathrm{H})(\mathrm{N}-\mathrm{H})$, $10.28(\mathrm{~s}, 1 \mathrm{H})(\mathrm{C}-\mathrm{OH}), 8.38(\mathrm{~s}, 1 \mathrm{H})(\mathrm{CH}=\mathrm{N}), 6.7-7.5(\mathrm{~m})$ $(\mathrm{CH}, \mathrm{CH} 2, \mathrm{CH} 3) ;{ }^{13} \mathrm{C}-\mathrm{NMR}$ data $(\delta$, ppm; DMSO): 176.60 $(\mathrm{C}=\mathrm{S}), 139.50$ (C-Ph).

L4: 2-methylindole-3-carboxaldehyde- $\mathrm{N}$-phenyl-thio semicarbazone. Yield: $80 \%$, M.p. $230^{\circ} \mathrm{C}$. Anal. Calc. for $\mathrm{C}_{17} \mathrm{H}_{16} \mathrm{~N}_{4} \mathrm{~S}: \mathrm{C}, 65.78 ; \mathrm{H}, 5.84 ; \mathrm{N}, 18.05$. Found: C, 66.01; H, 5.19; N, 17.32. IR data $\left(\mathrm{cm}^{-1}\right):(\mathrm{N}-\mathrm{H}) 3394.64,3285.30$. 3209.93, $(\mathrm{C}=\mathrm{N}) 1589.25(\mathrm{C}=\mathrm{S}) 839.31,{ }^{1} \mathrm{H}-\mathrm{NMR}$ data $(\delta$, ppm; DMSO): $11.55(\mathrm{~s}, 1 \mathrm{H})\left(\mathrm{N}-\mathrm{H}_{\text {indole }}\right) ; 11.40(\mathrm{~s}, 1 \mathrm{H})(\mathrm{N}-$ $\mathrm{H}), 9.50(\mathrm{~s}, 1 \mathrm{H})(\mathrm{N}-\mathrm{H}), 8.50(\mathrm{~s}, 1 \mathrm{H})(\mathrm{CH}=\mathrm{N}), 6.7-7.0(\mathrm{~m})$ $(\mathrm{CH}, \mathrm{CH} 2, \mathrm{CH} 3) ;{ }^{13} \mathrm{C}-\mathrm{NMR}$ data $(\delta, \mathrm{ppm} ; \mathrm{DMSO}): 174.50$ $(\mathrm{C}=\mathrm{S}), 141.70$ (C-Ph).

\section{L5: 5-chloroindole-3-carboxaldehde-N-phenyl-thio} semicarbazone. Yield: $45 \%$, M.p. $210^{\circ} \mathrm{C}$. Anal. Calc. for $\mathrm{C}_{16} \mathrm{H}_{15} \mathrm{ClN}_{4} \mathrm{~S}$ : C, 58.09; H, 4.57; N, 16.93. Found: C, 57.65; $\mathrm{H}, 3.95 ; \mathrm{N}, 16.20$. IR data $\left(\mathrm{cm}^{-1}\right):(\mathrm{N}-\mathrm{H}) 3338.98,3132.20$, $2973.42(\mathrm{C}=\mathrm{N}) 1609.25(\mathrm{C}=\mathrm{S}) 866.50,{ }^{1} \mathrm{H}-\mathrm{NMR}$ data $(\delta$, ppm; DMSO): $11.83(\mathrm{~s}, 1 \mathrm{H})(\mathrm{N}-\mathrm{H}), 11.58(\mathrm{~s}, 1 \mathrm{H})(\mathrm{N}-$ $\left.\mathrm{H}_{\text {indole }}\right), 9.72(\mathrm{~s}, 1 \mathrm{H})(\mathrm{N}-\mathrm{H}), 8.35(\mathrm{~s}, 1 \mathrm{H})(\mathrm{CH}=\mathrm{N}), 7.0-8.2$ (m) $(\mathrm{CH}, \mathrm{CH} 2, \mathrm{CH} 3){ }^{13} \mathrm{C}-\mathrm{NMR}$ data $(\delta$, ppm; DMSO): $175.10(\mathrm{C}=\mathrm{S}), 141.20(\mathrm{C}-\mathrm{Ph})$.

L6: 5-bromo-2-hydroxy-3-methoxybenzaldehyde- $\mathrm{N}$ phenyl-thiosemicarbazone. Yield: 70\%, M.p. $190{ }^{\circ} \mathrm{C}$. Anal. Calc. for $\mathrm{C}_{15} \mathrm{H}_{14} \mathrm{BrN}_{3} \mathrm{O}_{2} \mathrm{~S}$ : C, 47.38; $\mathrm{H}, 3.71 ; \mathrm{N}, 11.05$.
Found: C, 47.89; H, 3.75; N, 11.08. IR data $\left(\mathrm{cm}^{-1}\right):(\mathrm{N}-$ H) 3300.41, $2973.79(\mathrm{C}=\mathrm{N})$ 1604.00, $(\mathrm{C}=\mathrm{S}) 858.86 .1 \mathrm{H}-$ NMR data ( $\delta$, ppm; DMSO): $11.80(\mathrm{~s}, 1 \mathrm{H})(\mathrm{N}-\mathrm{H}), 10.10$ $(\mathrm{s}, 1 \mathrm{H})(\mathrm{N}-\mathrm{H}), 9.49(\mathrm{~s}, 1 \mathrm{H})(\mathrm{OH}), 8.43(\mathrm{~s}, 1 \mathrm{H})(\mathrm{CH}=\mathrm{N})$, $3.81(\mathrm{~s}, 1 \mathrm{H})\left(\mathrm{OCH}_{3}\right), 7.0-7.6(\mathrm{~m})(\mathrm{CH}, \mathrm{CH} 2, \mathrm{CH} 3) ;{ }^{13} \mathrm{C}-$ NMR data ( $\delta$, ppm; DMSO): $176.60(\mathrm{C}=\mathrm{S}), 140.00(\mathrm{C}-$ $\mathrm{Ph})$.

\section{Synthesis of complexes (P1-P6)}

$\mathrm{AgNO}_{3}(0.17 \mathrm{~g}, 1 \mathrm{mmol})$ was first dissolved in a 20 $\mathrm{mL}$ mixture of acetonitrile and methanol (2:3), following which the respective thiosemicarbazone ligands (L1-L6) $(2 \mathrm{mmol})$ were added. The mixture was refluxed at $55^{\circ} \mathrm{C}$ for 3-4 h. The mixture was further added with triphenylphosphine $(0.262 \mathrm{~g}, 1 \mathrm{mmol})$ in $5 \mathrm{~mL}$ of acetonitrile/methanol (2:3) and further refluxed for 2-3 more hours. The latter step could result in the solubilization of the precipitates obtained in the first step, if any. Thin-layer chromatography is used to monitor the reaction's progress. The resulting solution was filtered and later thoroughly dried via evaporation. Further purification was performed before the analysis. The silver complexes were brown and black powders and soluble in either DMSO or a mixture of methanol and acetonitrile.

P1: $\left[\mathrm{Ag}_{2}\left(\mathrm{PPh}_{3}\right)_{\mathbf{2}}(\mathrm{L1})_{4}\right] \cdot\left(\mathrm{NO}_{3}\right)_{2} \cdot \mathrm{H}_{2} \mathrm{O}$. Yield: $50 \%$, M.p. 157-160 ${ }^{\circ} \mathrm{C}$. Anal. Calc. for $\mathrm{C}_{92} \mathrm{H}_{78} \mathrm{Ag}_{2} \mathrm{~N}_{16} \mathrm{O}_{8} \mathrm{P}_{2} \mathrm{~S}_{4} \mathrm{C}$, 56.91; H, 4.05; N, 11.54; S, 6.61. Found: C, 56.30; H, 3.57; $\mathrm{N}, 11.65 ; \mathrm{S}, 6.61$. IR data $\left(\mathrm{cm}^{-1}\right):(\mathrm{N}-\mathrm{H}) 2983.12,2888.57$, $(\mathrm{C}=\mathrm{N}) 1589.21(\mathrm{C}=\mathrm{S})$ 840.88. ${ }^{1} \mathrm{H}-\mathrm{NMR}$ data $(\delta, \mathrm{ppm}$; DMSO): $12.33(\mathrm{~s}, 4 \mathrm{H})(\mathrm{N}-\mathrm{H}), 10.72(\mathrm{~s}, 4 \mathrm{H})(\mathrm{N}-\mathrm{H}), 8.18$ $(\mathrm{C}-\mathrm{H}, 4 \mathrm{H})(\mathrm{CH}=\mathrm{N}), 7.1-8.3(\mathrm{~m})(\mathrm{CH}, \mathrm{CH} 2, \mathrm{CH} 3) .{ }^{13} \mathrm{C}-$ NMR data ( $\delta$, ppm; DMSO): $175.80(\mathrm{C}=\mathrm{S}), 143.00(\mathrm{C}-$ $\mathrm{Ph}$ ).

P2: $\left[\mathrm{Ag}_{2}\left(\mathrm{PPh}_{3}\right)_{\mathbf{2}}(\mathbf{L 2})_{4}\right] \cdot\left(\mathrm{NO}_{3}\right)_{2} \cdot \mathrm{H}_{\mathbf{2}} \mathrm{O}$. Yield: $45 \%$, M.p. 135-138 ${ }^{\circ} \mathrm{C}$. ); Anal. Calc. for $\mathrm{C}_{92} \mathrm{H}_{82} \mathrm{Ag}_{2} \mathrm{~N}_{12} \mathrm{O}_{4} \mathrm{P}_{2} \mathrm{~S}_{4} \mathrm{C}$, 60.53; H, 4.53; N, 9.21; S, 7.03. Found: C, 58.90; H, 3.82; $\mathrm{N}, 9.26 ; \mathrm{S}, 6.48$. IR data $\left(\mathrm{cm}^{-1}\right):(\mathrm{N}-\mathrm{H}) 2981.06,2889.37$ $(\mathrm{C}=\mathrm{N})$ 1595.67, $(\mathrm{C}=\mathrm{S})$ 834.24. ${ }^{1} \mathrm{H}-\mathrm{NMR}$ data $(\delta, \mathrm{ppm}$; DMSO): $11.88(\mathrm{~s}, 4 \mathrm{H})(\mathrm{N}-\mathrm{H}), 10.22(\mathrm{~s}, 4 \mathrm{H})(\mathrm{N}-\mathrm{H}), 7.99$ $(\mathrm{s}, 4 \mathrm{H})(\mathrm{CH}=\mathrm{N}), 9.98(\mathrm{~s}, 4 \mathrm{H})(\mathrm{O}-\mathrm{H}), 6.6-7.5(\mathrm{~m})(\mathrm{CH}$, $\mathrm{CH} 2, \mathrm{CH} 3) ;{ }^{13} \mathrm{C}-\mathrm{NMR}$ data $(\delta, \mathrm{ppm} ; \mathrm{DMSO}): 173.90$ $(\mathrm{C}=\mathrm{S}), 146.60(\mathrm{C}-\mathrm{Ph})$. 
P3: $\left[\mathrm{Ag}_{2}\left(\mathrm{PPh}_{3}\right)_{\mathbf{2}}\left(\mathrm{L3}_{4}\right] \cdot\left(\mathrm{NO}_{3}\right)_{2} \cdot \mathrm{H}_{2}\right.$ O. Yield: $40 \%$. M.p. $140-$ $143{ }^{\circ} \mathrm{C}$. Anal. Calc. for: $\mathrm{C}_{92} \mathrm{H}_{78} \mathrm{Ag}_{2} \mathrm{Br}_{4} \mathrm{~N}_{12} \mathrm{O}_{4} \mathrm{P}_{2} \mathrm{~S}_{4} \mathrm{C}$, 51.60; $\mathrm{H}, 3.67$; N, 7.85; S, 5.99. Found: C, 49.65; H, 3.17; N, 7.81; $\mathrm{S}$, 5.31. IR data $\left(\mathrm{cm}^{-1}\right):(\mathrm{N}-\mathrm{H}) 3141.28,2984.50(\mathrm{C}=\mathrm{N})$ 1604.57, $(\mathrm{C}=\mathrm{S})$ 824.43. ${ }^{1} \mathrm{H}-\mathrm{NMR}$ data ( $\delta$, ppm; DMSO): $12.02(\mathrm{~s}, 4 \mathrm{H})(\mathrm{N}-\mathrm{H}), 10.46(\mathrm{~s}, 4 \mathrm{H})(\mathrm{N}-\mathrm{H}), 8.42(\mathrm{~s}, 4 \mathrm{H})$ $(\mathrm{CH}=\mathrm{N}), 10.58(\mathrm{~s}, 4 \mathrm{H})(\mathrm{O}-\mathrm{H})$ 6.8-7.5 (m) $(\mathrm{CH}, \mathrm{CH} 2$, $\mathrm{CH} 3) ;{ }^{13} \mathrm{C}-\mathrm{NMR}$ data $(\delta, \mathrm{ppm}$; DMSO): $174.00(\mathrm{C}=\mathrm{S})$, 141.50 (C-Ph).

P4: $\left[\mathrm{Ag}_{\mathbf{2}}(\mathbf{P P h})_{\mathbf{2}}(\mathbf{L 4})_{4}\right] \cdot\left(\mathrm{NO}_{3}\right)_{\mathbf{2}} \cdot \mathrm{H}_{\mathbf{2}} \mathrm{O}$. Yield: $45 \%$. M.p. $127-$ $130^{\circ} \mathrm{C}$. Anal. Calc. for $\mathrm{C}_{104} \mathrm{H}_{94} \mathrm{Ag}_{2} \mathrm{~N}_{16} \mathrm{P}_{2} \mathrm{~S}_{4} \mathrm{C}, 63.28 ; \mathrm{H}, 4.80$; $\mathrm{N}, 11.35 ; \mathrm{S}, 6.50$. Found: C, 59.62; H, 4.34; N, 10.98; S, 5.89. IR data $\left(\mathrm{cm}^{-1}\right):(\mathrm{N}-\mathrm{H}) 3012.28,2880.97,2649.02$ $(\mathrm{C}=\mathrm{N}) 1600.00(\mathrm{C}=\mathrm{S})$ 830.01. ${ }^{1} \mathrm{H}-\mathrm{NMR}$ data $(\delta$, ppm; DMSO): $11.63(\mathrm{~s}, 1 \mathrm{H})\left(\mathrm{N}-\mathrm{H}_{\text {indole }}\right), 11.60(\mathrm{~s}, 4 \mathrm{H})(\mathrm{N}-\mathrm{H})$, $9.73(\mathrm{~s}, 4 \mathrm{H})(\mathrm{N}-\mathrm{H}), 8.41(\mathrm{~s}, 4 \mathrm{H})(\mathrm{CH}=\mathrm{N}), 7-7.5(\mathrm{~m})(\mathrm{CH}$, $\mathrm{CH} 2, \mathrm{CH} 3) .{ }^{13} \mathrm{C}-\mathrm{NMR}$ data $(\delta, \mathrm{ppm}$; DMSO): 172.90 $(\mathrm{C}=\mathrm{S}), 144.00(\mathrm{C}-\mathrm{Ph})$.

P5: $\left[\mathrm{Ag}_{2}\left(\mathbf{P P h}_{3}\right)_{2}\left(\mathrm{LS}_{4}\right] \cdot\left(\mathrm{NO}_{3}\right)_{2} \cdot \mathrm{H}_{\mathbf{2}}\right.$ O. Yield: $40 \%$. M.p $131-$ $134^{\circ} \mathrm{C}$. Anal. Calc for $\mathrm{C}_{100} \mathrm{H}_{86} \mathrm{Ag}_{2} \mathrm{~N}_{16} \mathrm{P}_{2} \mathrm{~S}_{4} \mathrm{C}, 62.63 ; \mathrm{H}, 4.52$; N, 11.69; S, 6.69 Found: C, 59.89; H, 3.89; N, 10.91; S, 6.53. IR data $\left(\mathrm{cm}^{-1}\right)$ : $(\mathrm{N}-\mathrm{H}) 3000.96,2883.01,2733.51,(\mathrm{C}=\mathrm{N})$ 1598.27, $(\mathrm{C}=\mathrm{S})$ 834.04. ${ }^{1} \mathrm{H}-\mathrm{NMR}$ data ( $\delta$, ppm; DMSO): $11.88(\mathrm{~s}, 1 \mathrm{H})\left(\mathrm{N}-\mathrm{H}_{\text {indole }}\right), 10.35(\mathrm{~s}, 4 \mathrm{H})(\mathrm{N}-\mathrm{H}), 10.01(\mathrm{~s}$, $4 \mathrm{H})(\mathrm{N}-\mathrm{H}), 8.00(\mathrm{~s}, 4 \mathrm{H})(\mathrm{CH}=\mathrm{N}), 6.8-7.8(\mathrm{~m})(\mathrm{CH}, \mathrm{CH} 2$, $\mathrm{CH} 3) .{ }^{13} \mathrm{C}-\mathrm{NMR}$ data $(\delta, \mathrm{ppm}$; DMSO): $173.70(\mathrm{C}=\mathrm{S})$, 133.80 (C-Ph).

P6: $\left[\mathrm{Ag}_{2}\left(\mathbf{P P h}_{3}\right)_{2}\left(\mathbf{L 6}_{4}\right] \cdot\left(\mathrm{NO}_{3}\right)_{2} \cdot \mathrm{H}_{2}\right.$ O. Yield: $40 \%$. M.p $137-$ $140{ }^{\circ} \mathrm{C}$. Anal. Calc for $\mathrm{C}_{96} \mathrm{H}_{86} \mathrm{Ag}_{2} \mathrm{Br}_{4} \mathrm{~N}_{12} \mathrm{O}_{8} \mathrm{P}_{2} \mathrm{~S}_{4} \mathrm{C}, 50.99 ; \mathrm{H}$, 3.83; N, 7.43; S, 5.67. Found: C, 48.09; H, 3.38; N, 7.72; S, 6.02. IR data $\left(\mathrm{cm}^{-1}\right):(\mathrm{N}-\mathrm{H}) 3049.11,2879.23,(\mathrm{C}=\mathrm{N})$ $1599.12(\mathrm{C}=\mathrm{S}) 742.69 .{ }^{1} \mathrm{H}-\mathrm{NMR}$ data $(\delta, \mathrm{ppm}$; DMSO): $12.00(\mathrm{~s}, 4 \mathrm{H})(\mathrm{N}-\mathrm{H}), 10.53(\mathrm{~s}, 4 \mathrm{H})(\mathrm{N}-\mathrm{H}), 8.46(\mathrm{~s}, 4 \mathrm{H})$ $(\mathrm{CH}=\mathrm{N}), 9.52(\mathrm{~s}, 4 \mathrm{H})(\mathrm{O}-\mathrm{H}), 7.0-7.4(\mathrm{~m})(\mathrm{CH}, \mathrm{CH} 2$, $\mathrm{CH} 3) .{ }^{13} \mathrm{C}-\mathrm{NMR}$ data $(\delta, \mathrm{ppm} ; \mathrm{DMSO}): 174.40(\mathrm{C}=\mathrm{S})$, $836.84(\mathrm{C}-\mathrm{Ph})$

\section{Biological procedures}

Antiplasmodial assays. The antiplasmodial activities of all compounds were evaluated in vitro through HRP2 assays [16-17] as described in Ref. [18] with some alterations. First, the compounds were solubilized in $100 \%$ DMSO and serially diluted into mixtures whose concentrations range from $25 \mu \mathrm{M}$ to $0.39 \mu \mathrm{M}$ in wells $\mathrm{A} 1$ to A7 of a 96-well plate. Some $15 \mu \mathrm{L}$ of each seriallydiluted stock extract was moved accordingly into plates with $225 \mu \mathrm{L}$ of sterile $\mathrm{H}_{2} \mathrm{O}$. Aliquots from the plates would be used in the HRP2 assays. Next, ring-infected red blood cells (RBCs) of 5\% parasitemia were tuned so that the parasitemia and hematocrit were $0.05 \%$ and $1.5 \%$, respectively. Ten $\mu \mathrm{L}$ of each serially-diluted extract was moved to a test plate containing parasitized RBCs and later incubated in a candle jar at $37^{\circ} \mathrm{C}$ for $72 \mathrm{~h}$. The final test concentrations ranged from $0.156 \mu \mathrm{M}$ to 0.002 $\mu \mathrm{M}$, while DMSO was $0.3 \%$. Artemisinin (Art) (Sigma, USA), chloroquine (CQ) (Sigma, USA), mefloquine (Mef) (Sigma, USA), and quinine (Q) (Sigma, USA) whose final test concentrations were $1772.6-27.7 \mathrm{nM}$ for CQ, 3495-54.6 nM for Q, 601.3-9.4 nM for Mef, and 51.2-0.8 nM for Art - were the standard controls used to validate the test. Meanwhile, the negative controls comprised infected RBCs without extracts or with sterile $\mathrm{H}_{2} \mathrm{O}$ only. Following incubation for $72 \mathrm{~h}$, the test plates were then kept overnight at $-80^{\circ} \mathrm{C}$. It was then thawed at room temperature to lyse the infected RBCs. Subsequently, the activities of the compounds against the parasite were measured via HRP2 assays $[17,19]$.

Cytotoxicity assays (in vitro). The MDBK cells were preserved in complete Dulbecco's Modified Eagle Medium (DMEM) comprising $25 \mathrm{mM} \quad 4$-(2hydroxyethyl)-1-piperazineethanesulfonic acid (HEPES), $100 \mathrm{U}$ of Pen-strep (100 U penicillin and $100 \mathrm{U}$ streptomycin), $0.4 \%$ sodium bicarbonate $\left(\mathrm{NaHCO}_{3}\right)$ accompanied with $10 \%$ fetal bovine serum (FBS). 3-(4,5dimethylthiazol-2-yl)-2,5-diphenyltetrazolium bromide (MTT) assays were used to test the cytotoxicities of the extracts [20]. Briefly, MDBK cells $\left(1 \times 10^{3}\right.$ cells/well $)$ which have been cultured overnight were exposed to serially diluted (2-fold-diluted) compounds whose final concentrations ranged from $0.25 \mu \mathrm{M}$ to $0.004 \mu \mathrm{M}$. The final concentrations of DMSO in all tests were less than 1\%. All tests were performed in duplicates. Cell suspension lacking the test material was the positive control for cell growth, while the negative control cell contains suspension with $0.05 \%$ Triton $\mathrm{X} 100$. The test culture was kept for $72 \mathrm{~h}$ at $37^{\circ} \mathrm{C}$ in a $5 \% \mathrm{CO}_{2}$ incubator. To each well, some $50 \mu \mathrm{L}$ of MTT solution $(2.5 \mathrm{~mL}$ 
DMEM and $5 \mathrm{mg}$ MTT in $1 \mathrm{~mL}$ PBS) were added. It was then kept for $4 \mathrm{~h}$ at $37^{\circ} \mathrm{C}$ in the said incubator. Next, the medium was removed and replaced with $200 \mu \mathrm{L}$ of DMSO to solubilize the MTT formazan product. It was then mixed for $15 \mathrm{~min}$ before its absorbance was measured using a microplate reader (FLUOstar Omega, Germany) at $540 \mathrm{~nm}$. The $\mathrm{IC}_{50}$ and growth inhibition percentage were predicted with reference to a dose-response curve.

Antiproliferative assays. Sulforhodamine B (SRB) assays were performed to determine the $\mathrm{IC}_{50}$ of the test compounds as described in previous studies [21]. Briefly, the cells were treated with 5.053-161.686 $\mu \mathrm{M}, 4.843-$ $154.960 \mu \mathrm{M}, 4.189-134.055 \mu \mathrm{M}, 4.680-149.752 \mu \mathrm{M}$, or 3.936-125.944 $\mu \mathrm{M}$ sets of concentrations for all the synthesized complexes. Forty-eight hours later, using $50 \mu \mathrm{L}$ of $50 \%(\mathrm{w} / \mathrm{v})$ trichloroacetic acid (TCA), the cells were secured to the plates and kept further incubated at $4{ }^{\circ} \mathrm{C}$ for an hour. The plates were then washed five times using tap water, air-dried, stained with $100 \mu \mathrm{L}$ of $0.4 \%$ (w/v) SRB staining solution, and further incubated for another $10 \mathrm{~min}$ at room temperature. Consequently, the plates were washed three times with $1 \%(\mathrm{v} / \mathrm{v})$ acetic acid to remove the unbound stains. Following air-drying, $200 \mu \mathrm{L}$ of $10 \mathrm{mM}$ Trizma base was added into the wells, shaken for $10 \mathrm{~min}$. The reading of the absorbance is taken using a microplate reader at $490 \mathrm{~nm}$, and the $\mathrm{IC}_{50}$ calculated using the formula; $\mathrm{IC}_{50}=(\mathrm{OD}$ sample/OD control $) \times 100$. All experiments were performed in triplicates.

\section{- RESULTS AND DISCUSSION}

The six silver(I) complexes which were synthesized in a molar ratio of 1:1:2 (Ag: $\mathrm{PPh}_{3}$ :thiosemicarbazone) were either brown and black, were structurally characterized by nuclear magnetic resonance (NMR), Fourier-transform infrared (FTIR) spectroscopy, energydispersive X-ray (EDX), powder X-ray diffraction (PXRD), and elemental analysis. The spectroscopic data interpreted that all the ligands and their corresponding complexes existed in the form of thione tautomers. The formation of silver complexes occurred when silver received a lone pair of electrons from donor sulfur and phosphorus atoms. These complexes were believed to bind tightly to the metal center through M-S bridging bonds as they were synthesized in a molar ratio of 1:1:2 [22]. In agreement with the results of previous studies [22-23], the silver complexes were dinuclear, with each silver atom tetrahedrally coordinated to one $S$ atom with a thiosemicarbazone terminal, and two $S$ atoms with a bridging thiosemicarbazone group, and one $\mathrm{P}$ atom of triphenylphosphine $\left(\mathrm{PPh}_{3}\right)$ as shown in Fig. 1.

\section{Fourier-Transform Infrared Spectroscopy (FTIR)}

To investigate the points of attachment of the ligands to the metal center in the complexes, the FTIR spectra of the free ligands were compared to its synthesized complexes. The infrared spectra of the corresponding complexes confirmed the coordination of the ligand as $\mathrm{v}(\mathrm{C}=\mathrm{N})$ vibrational modes were detected in all of the ligands and complexes. The shifting of the $v(\mathrm{C}=\mathrm{S})$ bands to lower energies in the complexes meant that the thiosemicarbazone ligands were coordinated to the silver (I) metal via donor sulfur atoms. Meanwhile, the absence of $v(\mathrm{~S}-\mathrm{H})$ bands at the $2800-2550 \mathrm{~cm}^{-1}$ regions of both ligands and complexes revealed that the

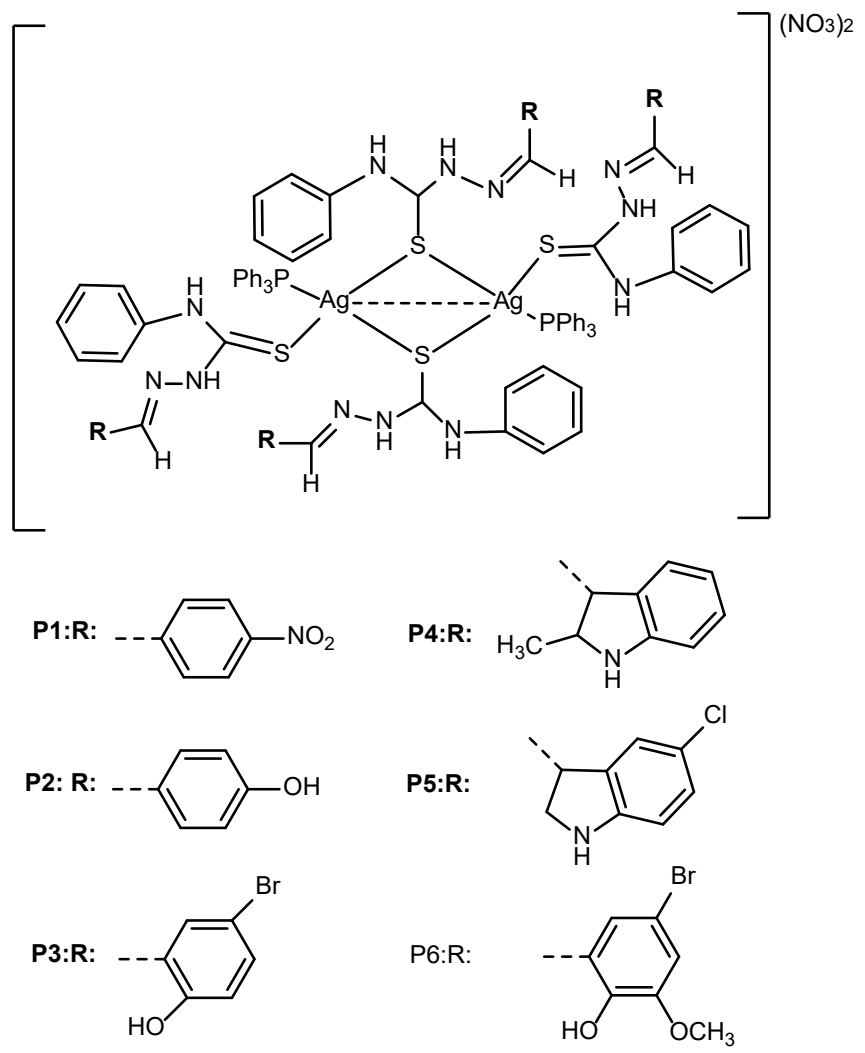

Fig 1. Structures of the silver complexes P1-P6 
complexes only had thione tautomers which were retained from their free ligands. Intra- and intermolecular hydrogen bonds of the hydroxyl and amino groups, which gave rise to band-broadening in the 3500$3000 \mathrm{~cm}^{-1}$ regions, were also present. A characteristic $v\left(\mathrm{P}-\mathrm{C}_{\mathrm{Ar}}\right)$ peak at around $1090 \mathrm{~cm}^{-1}$ denoted the presence of triphenylphosphine that was coordinated to the silver center. A sharp band around $1300 \mathrm{~cm}^{-1}$ was detected in all complexes, suggesting non-coordinated $\mathrm{NO}_{3}{ }^{-}$ions. However, the FTIR spectrum of $\mathbf{P 5}$ did not reveal a $-\mathrm{C}-$ $\mathrm{Cl}$ peak, unlike that of its ligand (L5). This occurrence further proposed the detachment of $-\mathrm{Cl}$ to form $\mathrm{HCl}$ in the reaction mixture.

\section{Nuclear Magnetic Resonance (NMR) Spectroscopy}

In the ${ }^{1} \mathrm{H}-\mathrm{NMR}$ spectra of the complexes, signals from the aromatic protons were confirmed by the presence of multiplet peaks observed at 6.00-8.00 ppm. Concurrently, following coordination with silver metal, the $\mathrm{N}-\mathrm{H}$ signals from the metal complexes were shifted downfield by around $0.20-0.50 \mathrm{ppm}$ from their original positions in the free ligands $(\delta=9.5-12.0 \mathrm{ppm})$. As for compounds P2, P3, and P6, the hydroxyl proton peaks at $\delta=9.98,10.58$, and $9.70 \mathrm{ppm}$ were also shifted slightly downfield. On the same note, $\mathbf{P 6}$ also gave rise to a methoxy-proton peak in the form of a triplet at $\delta=3.80$ ppm. The coordination of the triphenylphosphine ligand was evidenced by the presence of additional aromatic protons at $\delta=7.10-7.50 \mathrm{ppm}$ in the complexes; these were not otherwise present in their respective ligands. Fig. 2 shows the assignments of protons in the ${ }^{1} \mathrm{H}-\mathrm{NMR}$ spectrum of compounds 4 .

In the ${ }^{13} \mathrm{C}$-NMR spectra, the bonding between the thiosemicarbazone and phosphine ligands to the metal centers was also proven by the presence of $\mathrm{C}=\mathrm{S}$ signals in which the chemical shift value was around $2.0 \mathrm{ppm}$. This was in view of the decrease of the $\mathrm{C}=\mathrm{S}$ bond when attached to metal [24], as well as a shift in the $\mathrm{N} \rightarrow \mathrm{C}$ electron density, which gave rise to a partial bond characteristic in the $\mathrm{C}-\mathrm{N}$ bond [25]. With reference to compounds P2, P3, and P6, the C-hydroxyl resonance at the thiosemicarbazone ligand was observed at $\delta=139.00 \mathrm{ppm}$. In further detail, the spectrum for the

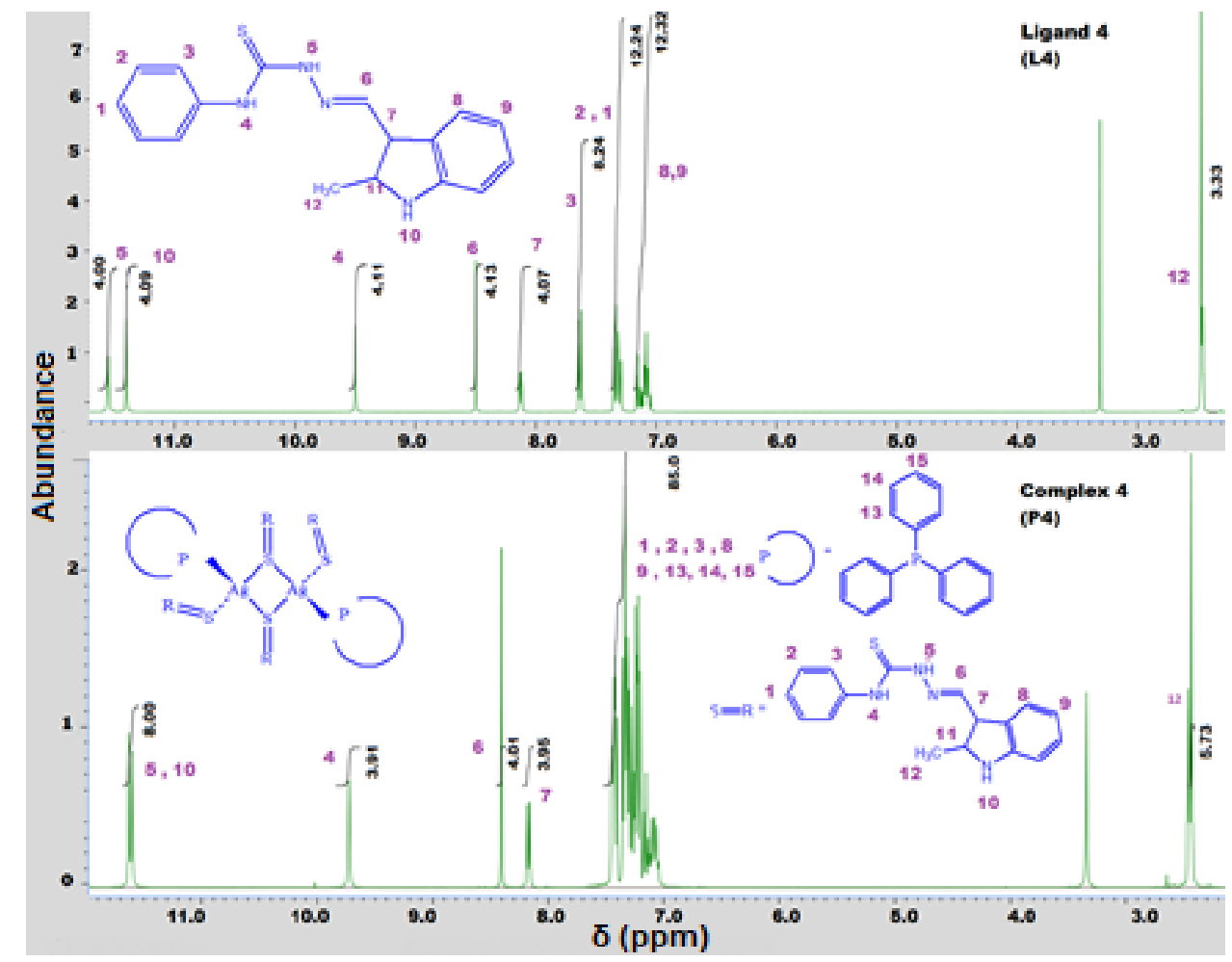

Fig 2. ${ }^{1} \mathrm{H}-\mathrm{NMR}$ spectra of compounds $\mathrm{L} 4$ and $\mathbf{P 4}$ 
compound $\mathbf{P 6}$ had a C-methoxy resonance at $\delta=57.0 \mathrm{ppm}$, while the $\mathrm{C}$-methyl resonance in compound $\mathbf{P 4}$ was observed at $\delta=12.0 \mathrm{ppm}$. In all complexes, the resonances of the aromatic carbons in triphenylphosphine and thiosemicarbazone revealed significant upfield shifts at $\delta$ $=131.0-132.0 \mathrm{ppm}$. Since the aromatic $\mathrm{C}$ on triphenylphosphine appeared as doublets and singlet, these further confirmed the attachment of the triphenylphos phine ligand to the silver center [25]. Fig. 3 shows the assignments of carbon peaks for the ligand and complex 4 .
The ${ }^{1} \mathrm{H}-{ }^{1} \mathrm{H}$ COSY NMR has further authenticated the correlation between the equivalent proton pairs with the adjacent protons wherein the cross peak resulting from the correlation appears in the same region. Fig. 4 shows the COSY spectrum for complexes P3. From the figure, the proton $\mathrm{H} 5$ is correlated to the proton $\mathrm{H} 4$ and H6. Meanwhile, H10 is correlated to the aromatic proton area near $7 \mathrm{ppm}$. A similar phenomenon can also be found by $\mathrm{H} 7$ which correlates with the aromatic proton area near $7 \mathrm{ppm}$ while the $\mathrm{H} 8$ correlates to the aromatic

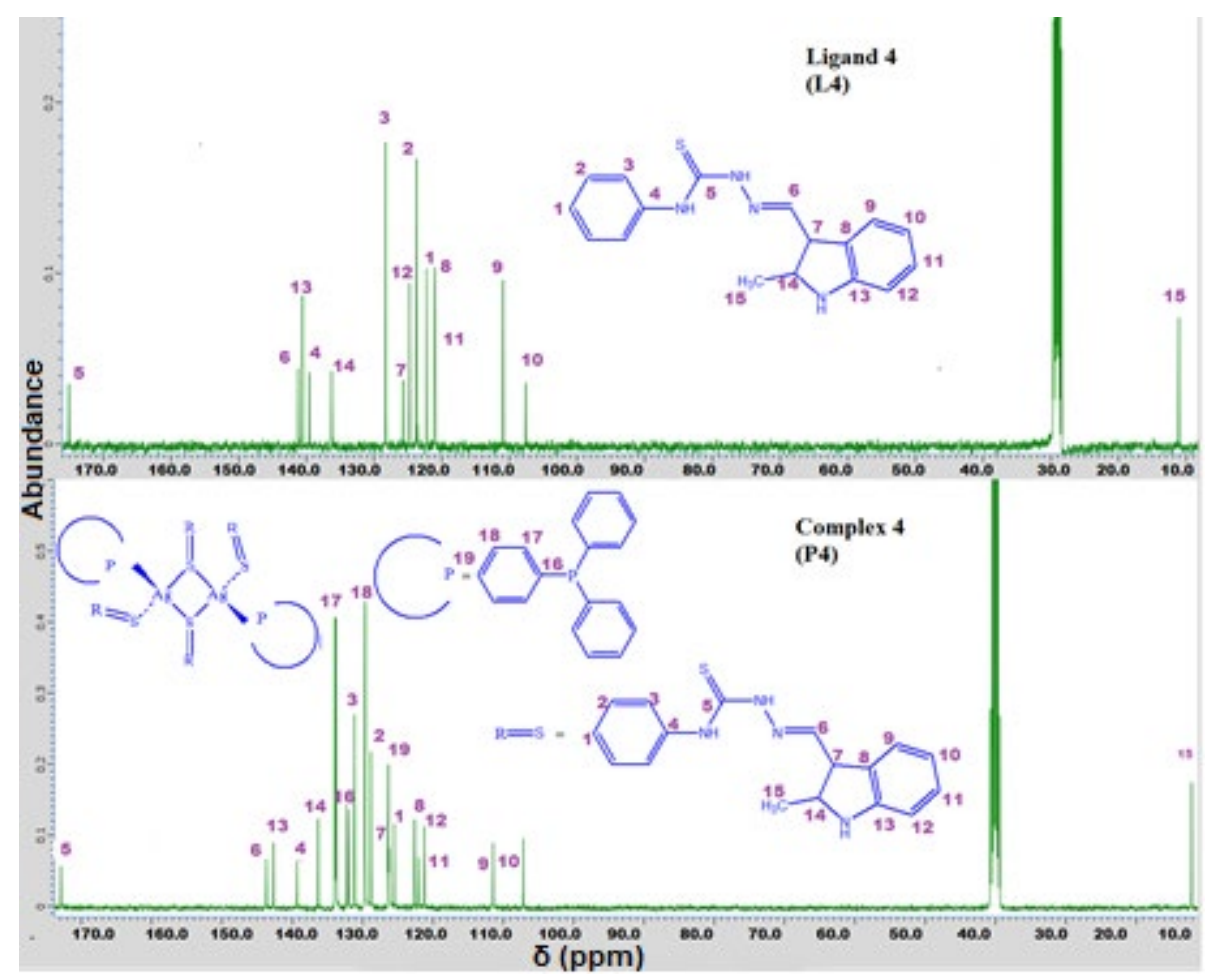

Fig 3. ${ }^{13} \mathrm{C}$-NMR spectra of $\mathbf{L} 4$ and $\mathbf{P 4}$

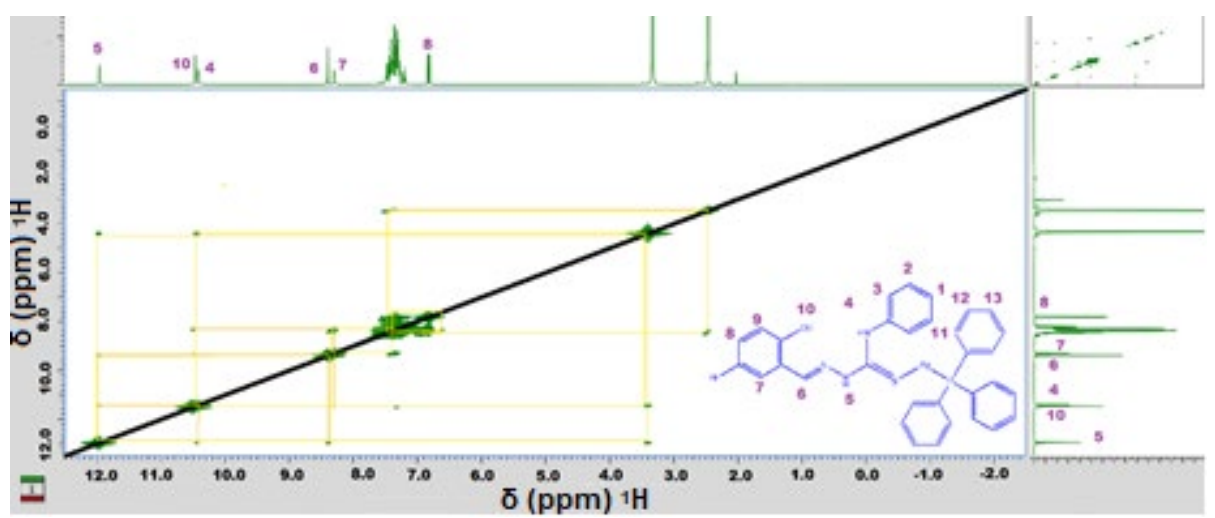

Fig 4. COSY NMR spectrum of complexes P3 
proton peak indisputably H9. The COSY spectra also reveal that the $\mathrm{H} 10$ adjacent to the $\mathrm{O}$ atom in the hydroxyl group and $\mathrm{H} 5$ connected to the $\mathrm{N}$ atom is correlated with the $\mathrm{H}_{2} \mathrm{O}$ peak from the deuterated DMSO.

The ${ }^{1} \mathrm{H}-{ }^{13} \mathrm{C}$ HSQC spectra of compounds demonstrate the interaction between the protons and the carbon atoms which are attached. As a representative, the discussion will be based on the spectrum for ligand and complex P6 (Fig. 5). It can be deduced from Fig. 2 that the H6 is correlated with C6. A similar phenomenon can also be found on the $\mathrm{H} 8$, which relates to $\mathrm{C} 10$ as justified in the structure numbering shown in the figure. The aromatic carbons in the compound were established via the connectivities between the carbon and its neighboring proton by HSQC correlation spectra. H1, H2, H3, H11, $\mathrm{H} 12, \mathrm{H} 13$, and $\mathrm{H} 7 \mathrm{in}$ the aromatic ring are correlated with C1, C2, C3, C14, C15, C16, and C8, respectively.

In the ${ }^{31} \mathrm{P}\left\{{ }^{1} \mathrm{H}\right\}-\mathrm{NMR}$ spectra of complexes $\mathbf{P 1}$ to $\mathbf{P 6}$, a sharp singlet was observed at $\delta=10.0 \mathrm{ppm}$. This result suggested that the resonance of phosphorus in triphenylphosphine has shifted downfield as compared to that of its free ligand [13] ( $\delta=-5.5 \mathrm{ppm})$. In other words, complexation occurred between the silver center and the triphenylphosphine ligand. Fig. 6 shows the ${ }^{31} \mathrm{P}$ NMR spectra of triphenylphosphine and silver complex P4.

\section{Powder X-Ray Diffraction (PXRD) Analysis}

To produce sufficient crystals for single-crystal Xray analyses, the crystals of all synthesized complexes were grown several times using various methods, including those of previous studies that have managed to generate single crystals [22-26]. Some of these methods included slow evaporation at room temperature and low temperature (refrigerator) for several days, as well as recrystallization of the products scraped from organic solvents (DMF, DMSO, acetonitrile, methanol). However, crystals were not successfully grown that can be further used for X-ray diffraction studies. According to Altaf et al., silver compounds whose ligands contained

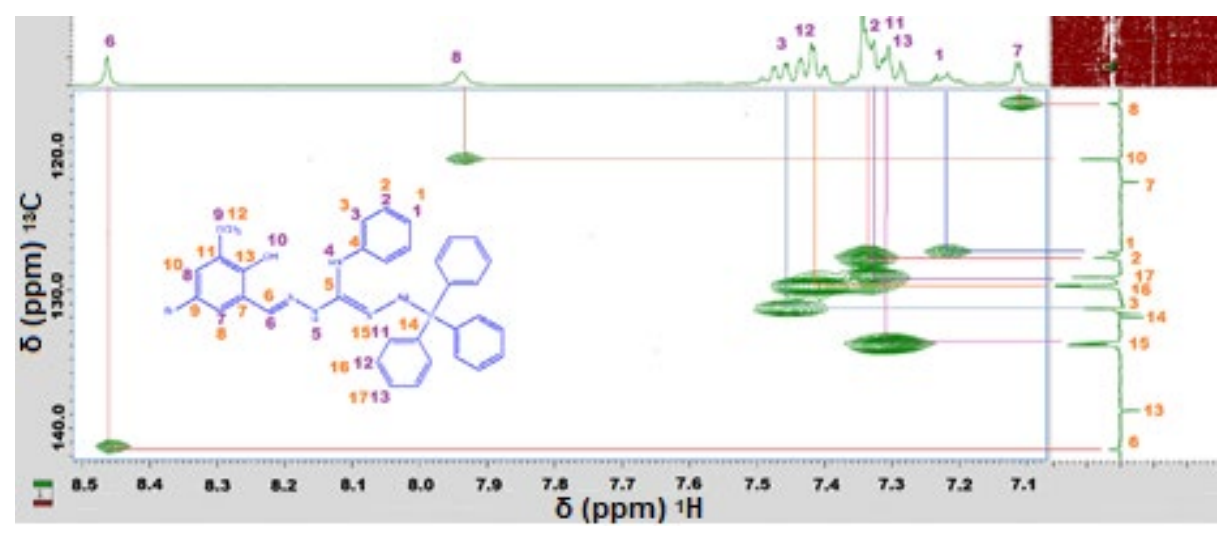

Fig 5. HSQC spectrum for complexes $\mathbf{P 6}$

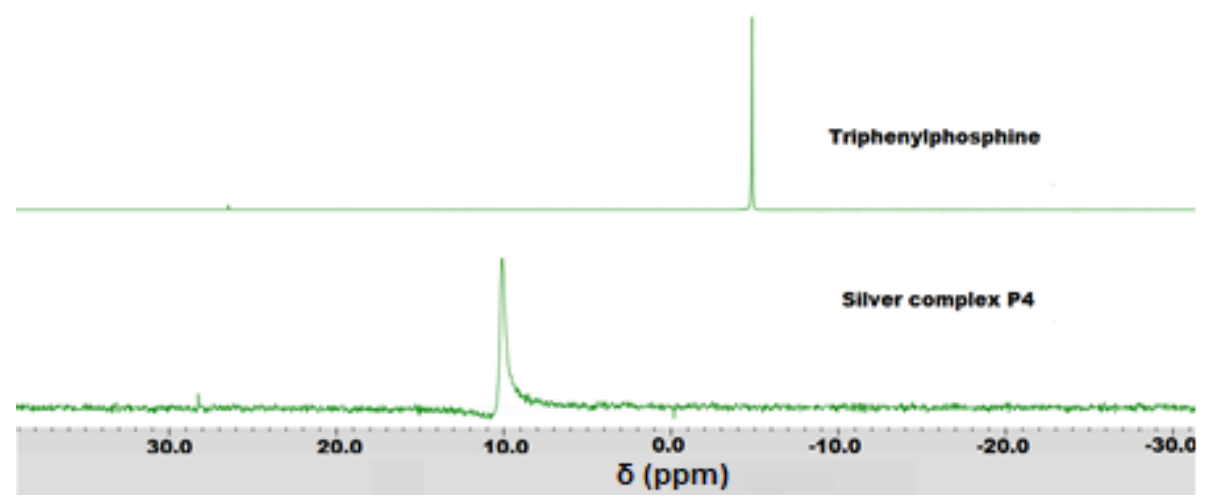

Fig 6. ${ }^{31} \mathrm{P}\left\{{ }^{1} \mathrm{H}\right\} \mathrm{C}-\mathrm{NMR}$ spectra of free ligand (triphenylphosphine) and silver complex 
nitrogen and sulfur were hard to crystallize owing to their tendency to form intramolecular interactions and polymeric states [22]. Thus, we probed the complexes via PXRD analysis to determine their phases, unit cell dimensions, as well as sample purities. Fig. 7 shows the PXRD pattern for compound 5 (L5 and P5). All other diffractograms can be found in Supplementary Information associated with this report. The PXRD diffractograms were taken within $2 \theta$ ranges of $5-40^{\circ}$. The observed broad peaks were attributed to the noncrystalline samples.

\section{Energy Dispersive X-ray (EDX) Spectroscopy}

EDX spectroscopy was also conducted to verify the existence of silver metal in all complexes (see Supplementary Information). Based on the results of the analyses, silver metal was present in all six series of complexes. Other elements such as carbon, nitrogen, oxygen, sulfur, phosphorus, and bromine, which were expected to be present in the ligands, were also present in the complexes.

\section{Antiplasmodial Study}

All complexes demonstrate suitable antiplasmodial activities in the in vitro P. falciparum HRP2 assays against chloroquine-resistant $P$. falciparum parasites (in the asexual cycle) in red blood cells (Table 1). All silver complexes (except P1) were tested for this study. The cytotoxic activity of the compounds on MDBK cells was evaluated in terms of the proportion of cytotoxicity to biological activity (SI). The biological efficacy was not attributable to in vitro cytotoxicity when the index was $\geq 10$ [27]. However, the compounds better inhibited the growths of normal cell lines, MDBK cells,

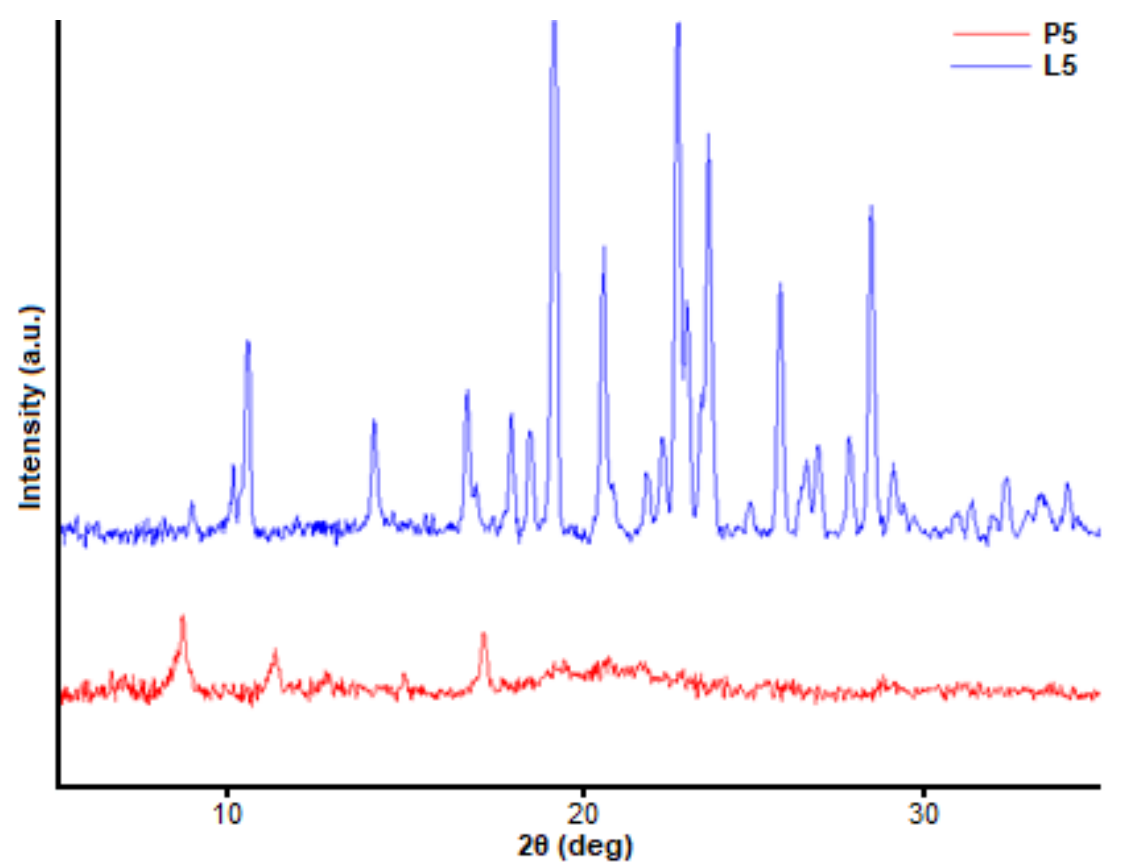

Fig 7. PXRD diffractograms of ligand and complex P5

Table 1. Antiplasmodial and cytotoxicity activity of silver complexes 1-6 (EC50 in $\mu \mathrm{M})$

\begin{tabular}{cccc}
\hline Complexes & P. falciparum HRP2 & Normal MDBK & Selectivity Index (SI) \\
\hline P1 & - & - & - \\
P2 & $1.739 \pm 0.243$ & $1.215 \pm 0.180$ & 0.699 \\
P3 & $4.000 \pm 0.142$ & $0.821 \pm 0.068$ & 0.205 \\
P4 & $2.120 \pm 1.184$ & $0.945 \pm 0.102$ & 0.446 \\
P5 & $3.776 \pm 0.280$ & $0.984 \pm 0.046$ & 0.261 \\
P6 & $4.266 \pm 0.311$ & $1.675 \pm 0.183$ & 0.393 \\
\hline
\end{tabular}


than P. falciparum (Table 1). Specifically, the SI of each compound was less than 10 , thereby suggesting that the antiplasmodial activities of the compounds could be due to in vitro cytotoxicity.

Concerning the selectivity indices of silver complexes, P2 had the highest SI (0.699) while P3 the lowest (0.205). This could be explained by the existence of a hydroxyl group at the -para position in $\mathbf{P 2}$ rather than the -ortho position in P3. Additionally, the latter complex also contained a bromide group at the -meta position. Meanwhile, the presence of a methoxy group at the -meta position in $\mathbf{P 6}$ caused a higher SI value of 0.393 than that of P3. Based on the results of previous studies, the insertion of methyl [28] and hydroxyl [29-30] groups into the compounds enhanced the antiplasmodial activity. Nonetheless, it remained uncertain for the role of each functional group in improving the selectivity of the silver complexes.

\section{Antiproliferative Activities}

Transition metals like silver have long been known to be antimicrobial agents. However, there is still much to be discovered concerning its ability to act as an anticancer agent [31-32], even though there are reports that silver has anticancer activity in vitro [33]. The advantage of silver is that its toxicity is lower than those of other metals like platinum (e.g., cisplatin) [34]. On another note, thiosemicarbazones have a wide range of antiproliferative activities on different tumor cell lines, apart from displaying the common features of all compounds with carcinogenic potencies [35-36]. Meanwhile, silver phosphine has been shown to exert in vitro antiproliferative effects [37-38]. Based on the $\mathrm{IC}_{50}$ values, complexes P2, P3, P4, P5, and P6 exerted modest antiproliferative effects on the human breast cancer MCF-7 and colon cancer HT-29 cell lines (Table 2). However, $\mathbf{P 1}$ had the weakest antiproliferative potential in all cancer cell lines tested. However, as for the MDAMB-231 carcinoma cancer cell line, good antiproliferative effects were also observed for P2, P4, and P5. This might be due to the hydroxyl group's presence [39] in P2 and the indolic group of P4 and P5. Therefore, more in-depth studies are warranted concerning the roles of these silver compounds as metallotherapeutic drugs for cancers.
Table 2. Antiproliferative activities of silver complexes 1-6 (IC50 in $\mu \mathrm{M})$

\begin{tabular}{cccc}
\hline Complexes & MDA-MB-231 & HT-29 & MCF-7 \\
\hline P1 & $15.11 \pm 4.24$ & - & $19.62 \pm 4.87$ \\
P2 & $6.81 \pm 1.69$ & $7.23 \pm 0.10$ & $4.48 \pm 0.86$ \\
P3 & - & $6.86 \pm 0.17$ & $3.51 \pm 1.13$ \\
P4 & $5.48 \pm 1.16$ & $5.79 \pm 1.92$ & $7.13 \pm 0.71$ \\
P5 & $5.27 \pm 1.44$ & $6.03 \pm 0.76$ & $4.34 \pm 1.69$ \\
P6 & - & $7.14 \pm 0.76$ & $4.39 \pm 0.74$ \\
\hline
\end{tabular}

\section{- CONCLUSION}

Six silver complexes containing mixed ligands (4phenyl-3-thiosemicarbazone derivatives and triphenylphosphine) have been successfully synthesized. The silver complexes were found to be dinuclear with tetrahedral geometry supported by the spectroscopic data discussed in the earlier section. Antiproliferative activities were investigated using MCF-7 breast and MDA-MB-231 carcinoma cancer cell lines and the HT29 colon cancer cell line. Compounds P2-P6 were worthy of in-depth studies as metallotherapeutic agents as their result exerted modest antiplasmodial activity against most cancer cells tested. On another note, all the compounds mentioned above had good activity against chloroquine-resistant $P$. falciparum parasites, but they were not as selective as conventional drugs. Consequently, modifications of the structural frame of 4-phenyl-3-thiosemicarbazone could improve the SI value of the resulting compound.

\section{- ACKNOWLEDGMENTS}

This work was supported by the Geran Penyelidikan Universiti Malaya (UMRG) - AFR Frontier Science (Grant no. RG357-15AFR) and University of Malaya IPPP Grant (Grant no. PG002-2015A).

\section{- AUTHOR CONTRIBUTIONS}

The project was conceived by Rozie Sarip and Nor Fadilah Rajab. Chemical synthesis and characterizations were performed mainly by Nur Adila Fatin Mohd Khir with the help of Nur Rahimah Fitrah Mohd Sofyan. Invitro studies of the antiplasmodial and antiproliferative activity were done by Mohd Ridzuan Mohd Abd Razak and Fariza Juliana Nordin, respectively. The manuscript 
was written by Nur Adila Fatin Mohd Khir, Mohd Ridzuan Mohd Abd Razak, Fariza Juliana Nordin, and Rozie Sarip.

\section{- REFERENCES}

[1] Chen, J.J., Gan, Z.L., Huang, Q., and Yi, X.Y., 2017, Well-defined dinuclear silver phosphine complexes based on nitrogen donor ligand and their high efficient catalysis for $\mathrm{A}^{3}$-coupling reaction, Inorg. Chim. Acta, 466, 93-99.

[2] Papanikolaou, P.A., Papadopoulos, A.G., Andreadou, E.G., Hatzidimitriou, A., Cox, P.J., Pantazaki, A.A., and Aslanidis, P., 2015, The structural and electronic impact on the photophysical and biological properties of a series of $\mathrm{Cu}^{\mathrm{I}}$ and $\mathrm{Ag}^{\mathrm{I}}$ complexes with triphenylphosphine and pyrimidine-type thiones, New J. Chem., 39 (6), 4830-4844.

[3] Engelbrecht, Z., Meijboom, R., and Cronjé, M.J., 2018, The ability of silver(I) thiocyanate 4methoxyphenyl phosphine to induce apoptotic cell death in esophageal cancer cells is correlated to mitochondrial perturbations, BioMetals, 31 (2), 189202.

[4] Human, Z., Munyaneza, A., Omondi, B., Sanabria, N.M., Meijboom, R., and Cronjé, M.J., 2014, The induction of cell death by phosphine silver(I) thiocyanate complexes in SNO-esophageal cancer cells, BioMetals, 28 (1), 219-228.

[5] Chaves, J.D.S., Neumann, F., Francisco, T.M., Corrêa, C.C., Lopes, M.T.P., Silva, H., Fontes, A.P.S., and de Almeida, M.V., 2014, Synthesis and cytotoxic activity of gold(I) complexes containing phosphines and 3-benzyl-1,3-thiazolidine-2-thione or 5-phenyl1,3,4-oxadiazole-2-thione as ligands, Inorg. Chim. Acta, 414, 85-90.

[6] Adams, M., Barnard, L., de Kock, C., Smith, P.J., Wiesner, L., Chibale, K., and Smith, G.S., 2016, Cyclopalladated organosilane-tethered thiosemicar bazones: Novel strategies for improving antiplasmodial activity, Dalton Trans., 45 (13), 5514-5520.

[7] Haas, K.L., and Franz, K.J., 2009, Application of metal coordination chemistry to explore and manipulate cell biology, Chem. Rev., 109 (10), 4921-4960.

[8] Viñuelas-Zahínos, E., Luna-Giles, F., TorresGarcia, P., and Fernández-Calderón, M.C., 2011, $\mathrm{Co}(\mathrm{III}), \mathrm{Ni}(\mathrm{II}), \mathrm{Zn}(\mathrm{II})$ and $\mathrm{Cd}(\mathrm{II})$ complexes with 2acetyl-2-thiazoline thiosemicarbazone: Synthesis, characterization, X-ray structures and antibacterial activity, Eur. J. Med. Chem., 46 (1), 150-159.

[9] Mustafa, A.Z.A., Altaf, M., Monim-ul-Mehboob, M., Fettouhi, M., Wazeer, M.I.M., Isab, A.A., Dhuna, V., Bhatia, G., and Dhuna, K., 2014, Tetrakis(1-3diazinane-2-thione)platinum(II) chloride monohydrate complex: Synthesis, spectroscopic characterization, crystal structure and in vitro cytotoxic activity against A549, MCF7, HCT15 and HeLa human cancer lines, Inorg. Chem. Commun., 44, 159-163.

[10] Netalkar, P.P., Netalkar, S.P., and Revankar, V.K., 2014, Nickel(II) complexes of thiosemicarbazones: synthesis, characterization, X-ray crystallographic studies and in vitro antitubercular and antimicrobial studies, Transition Met. Chem., 39 (5), 519-526.

[11] Shahsavani, E., Khalaji, A.D., Feizi, N., Kučeráková, M., and Dušek, M., 2015, Synthesis, characterization, crystal structure and antibacterial activity of new sulfur-bridged dinuclear silver(I) thiosemicarbazone complex $\quad \mathrm{Ag}_{2}\left(\mathrm{PPh}_{3}\right)_{2}(\mu-\mathrm{S}$ Brcatsc $\left.)_{2}\left(\eta^{1}-\mathrm{S}-\text { Brcatsc }\right)_{2}\right]\left(\mathrm{NO}_{3}\right)_{2}$, Inorg. Chim. Acta, 429, 61-66.

[12] Hemmert, C., Fabié, A., Fabre, A., Benoit-Vical, F., and Gornitzka, H., 2013, Synthesis, structures, and antimalarial activities of some silver(I), gold(I) and gold(III) complexes involving $N$-heterocyclic carbene ligands, Eur. J. Med. Chem., 60, 64-75.

[13] Isab, A.A., Nawaz, S., Saleem, M., Altaf, M., Monim-ul-Mehboob, M., Ahmad, S., and Evans, H.S., 2010, Synthesis, characterization and antimicrobial studies of mixed ligand silver(I) complexes of thioureas and triphenylphosphine; crystal structure of $\left\{\left[\mathrm{Ag}\left(\mathrm{PPh}_{3}\right)\right.\right.$ (thiourea) $\left.\left.\left(\mathrm{NO}_{3}\right)\right]_{2} \cdot\left[\mathrm{Ag}\left(\mathrm{PPh}_{3}\right) \text { (thiourea) }\right]_{2}\left(\mathrm{NO}_{3}\right)_{2}\right\}$, Polyhedron, 29 (4), 1251-1256. 
[14] Chaves, J.D.S., Tunes, L.G., de J. Franco, C.H., Francisco, T.M., Corrêa, C.C., Murta, S.M.F., MonteNeto, R.L., Silva, H., Fontes, A.P., and de Almeida, M.V., 2017, Novel gold(I) complexes with 5-phenyl1,3,4-oxadiazole-2-thione and phosphine as potential anticancer and antileishmanial agents, Eur. J. Med. Chem., 127, 727-739.

[15] Benmohammed, A., Khoumeri, O., Djafri, A., Terme, T., and Vanelle, P., 2014, Synthesis of novel highly functionalized 4-thiazolidinone derivatives from 4phenyl-3-thiosemicarbazones, Molecules, 19 (3), 3068-3083.

[16] Noedl, H., Bronnert, J., Yingyuen, K., Attlmayr, B., Kollaritsch, H., and Fukuda, M., 2005, Simple histidine-rich protein 2 double-site sandwich enzyme-linked immunosorbent assay for use in malaria drug sensitivity testing, Antimicrob. Agents Chemother., 49 (8), 3575-3577.

[17] Noedl, H., Wernsdorfer, W.H., Miller, R.S., and Wongsrichanalai, C., 2002, Histidine-rich protein II: A novel approach to malaria drug sensitivity testing, Antimicrob. Agents Chemother., 46 (6), 1658-1664.

[18] Mohd Abd Razak, M.R., Afzan, A., Ali, R., Amir Jalaluddin, N.F., Wasiman, M.I., Shiekh Zahari, S.H., Abdullah, N.R., and Ismail, Z., 2014, Effect of selected local medicinal plants on the asexual blood stage of chloroquine resistant Plasmodium falciparum, BMC Complementary Altern. Med., 14 (1), 492.

[19] Noedl, H., Wernsdorfer, W.H., Kollaritsch, H., Looareesuwan, S., Miller, R.S., and Wongsrichanalai, C., 2003, Malaria drug-susceptibility testing. HRP2based assays: current data, future perspectives, Wien. Klin. Wochenschr., 115 (Suppl. 3), 23-27.

[20] Mosmann, T., 1983, Rapid colorimetric assay for cellular growth and survival: Application to proliferation and cytotoxicity assays, J. Immunol. Methods, 65 (1-2), 55-63.

[21] Vichai, V., and Kirtikara, K., 2006, Sulforhodamine B colorimetric assay for cytotoxicity screening, Nat. Protocols, 1 (3), 1112-1116.

[22] Altaf, M., Stoeckli-Evans, H., Cuin, A., Sato, D.N., Pavan, F.R., Leite, C.Q.F., Ahmad, S., Bouakka, M., Mimouni, M., Khardli, F.Z., and Hadda, T.B., 2013,
Synthesis, crystal structures, antimicrobial, antifungal and antituberculosis activities of mixed ligand silver(I) complexes, Polyhedron, 62, 138-147.

[23] Sultana, R., Lobana, T.S., Sharma, R., Castineiras, A., Akitsu, T., Yahagi, K., and Aritake, Y., 2010, Heterocyclic thioamide derivatives of coinage metals $(\mathrm{Cu}, \mathrm{Ag})$ : Synthesis, structures and spectroscopy, Inorg. Chim. Acta, 363 (13), 34323441.

[24] Sharma, R., Lobana, T.S., Kaur, M., Thathai, N., Hundal, G., Jasinski, J.P., and Butcher, R.J., 2016, Variable coordinating activity of sulfur in silver(I) complexes with thiophene based $\mathrm{N}$-1-substituted thiosemicarbazones: First case of thiopheneylthione sulfur bridging in a dinuclear complex, $J$. Chem. Sci., 128 (7), 1103-1112.

[25] Nawaz, S., Isab, A.A., Merz, K., Vasylyeva, V., Metzler-Nolte, N., Saleem, M., and Ahmad, S., 2011, Synthesis, characterization and antimicrobial studies of mixed ligand silver(I) complexes of triphenylphosphine and heterocyclic thiones: Crystal structure of bis $\left[\left\{\left(\mu^{2}\right.\right.\right.$-diazinane-2-thione)(diazinane -2-thione)(triphenylphosphine)silver(I) nitrate\}], Polyhedron, 30 (9), 1502-1506.

[26] Venkatachalam, T.K., Pierens, G.K., Bernhardt, P.V., Stimson, D.H.R., Bhalla, R., Lambert, L., and Reutens, D.C., 2016, Heteronuclear NMR spectroscopic investigations of gallium complexes of substituted thiosemicarbazones including X-ray crystal structure, a new halogen exchange strategy, and ${ }^{18} \mathrm{~F}$ radiolabelling, Aust. J. Chem., 69 (9), 1033-1048.

[27] Waiganjo, B., Moriasi, G., Onyancha, J., Elias, N., and Muregi, F., 2020, Antiplasmodial and cytotoxic activities of extracts of selected medicinal plants used to treat malaria in Embu county, Kenya, J. Parasitol. Res., 2020, 8871375.

[28] Souza, M.C., Padua, T.A., Torres, N.D., Costa, M.F.S., Facchinetti, V., Gomes, C.R.B., Souza, M.V.N., and Henriques, M.G., 2015, Study of the antimalarial properties of hydroxyethylamine derivatives using green fluorescent protein transformed Plasmodium berghei, Mem. Inst. Oswaldo Cruz, 110 (4), 560-565. 
[29] Loginova, N.V., Koval'chuk, T.V., Gres, A.T., Osipovich, N.P., Polozov, G.I., Halauko, Y.S., Faletrov, Y.V., Harbatsevich, H.I., Hlushko, A.V., Azarko, I.I., and Bokshits, Y.V., 2015, Redox-active metal complexes of sterically hindered phenolic ligands: Antibacterial activity and reduction of cytochrome c. Part IV. Silver(I) complexes with hydrazone and thiosemicarbazone derivatives of 4,6-di-tert-butyl2,3-dihydroxybenzaldehyde, Polyhedron, 88, 125-137.

[30] Wani, W.A., Jameel, E., Baig, U., Mumtazuddin, S., and Hun, L.T., 2015, Ferroquine and its derivatives: New generation of antimalarial agents, Eur. J. Med. Chem., 101, 534-551.

[31] Medici, S., Peana, M., Nurchi, V.M., Lachowicz, J.I., Crisponi, G., and Zoroddu, M.A., 2015, Noble metals in medicine: Latest advances, Coord. Chem. Rev., 284, 329-350.

[32] Banti, C.N., and Hadjikakou, S.K., 2013, Antiproliferative and anti-tumor activity of silver(I) compounds, Metallomics, 5 (6), 569-596.

[33] Majeed, S., Abdullah, M.S., Nanda, A., and Ansari, M.T., 2016, In vitro study of the antibacterial and anticancer activities of silver nanoparticles synthesized from Penicillium brevicompactum (MTCC-1999), J. Taibah Univ. Sci., 10 (4), 614-620.

[34] Ndagi, U., Mhlongo, N., and Soliman, M.E., 2017, Metal complexes in cancer therapy - an update from drug design perspective, Drug Des., Dev. Ther., 11, 599-616.

[35] Arora, S., Agarwal, S., and Singhal, S., 2014, Anticancer activities of thiosemicarbazides/thio semicarbazones: A review, Int. J. Pharm. Pharm. Sci., 6 (9), 34-41.

[36] Serda, M., Kalinowski, D.S., Rasko, N., Potůčková, E., Mrozek-Wilczkiewicz, A., Musiol, R., Małecki, J.G., Sajewicz, M., Ratuszna, A., Muchowicz, A., Gołąb, J., Šimůnek, T., Richardson, D.R., and Polanski, J., 2014, Exploring the anti-cancer activity of novel thiosemicarbazones generated through the combination of retro-fragments: Dissection of critical structure-activity relationships, Plos One, 9 (10), e110291.

[37] Human-Engelbrecht, Z., Meijboom, R., and Cronjé, M.J., 2017, Apoptosis-inducing ability of silver(I) cyanide-phosphines useful for anti-cancer studies, Cytotechnology, 69 (4), 591-600.

[38] Kyros, L., Kourkoumelis, N., Kubicki, M., Male, L., Hursthouse, M.B., Verginadis, I.I., Gouma, E., Karkabounas, S., Charalabopoulos, K., and Hadjikakou, S.K., 2010, Structural properties, cytotoxicity, and anti-inflammatory activity of silver(I) complexes with tris( $p$-tolyl)phosphine and 5-chloro-2-mercaptobenzothiazole, Bioinorg. Chem. Appl., 2010, 386860.

[39] Abdul Halim, S.N.A., Nordin, F.J., Mohd Abd Razak, M.R., Mohd Sofyan, N.R.F., Abdul Halim, S.N., Rajab, N.F., and Sarip, R., 2019, Synthesis, characterization, and evaluation of silver(I) complexes with mixed-ligands of thiosemicarbazones and diphenyl $(p$ tolyl)phosphine as biological agents, J. Coord. Chem., 72 (5-7), 879-893. 